Проф. др Радојка Вукчевић

Универзитет у Београду

Филолошки факултет

821.163.41.09 Андрић И.

vukcevicradojka@gmail.com https://doi.org/10.18485/ai_andric.2018.ch2

\title{
МОСТ СИЛИЈЕ ХОКСВОРТ \\ ИЗМЕЂУ ИСТОКА И ЗАПАДА
}

У раду he се представити допринос Силије Хоксворт (Celia Hawkesworth) у грађењу моста између наше и англосаксонске културе: ауторкино служење „човеку и човечности“, кроз анализу њене студије Иво Анgрић између Истиока и Зайaga (Ivo Andrić: Bridge Between East and West). Подробно ће се анализирати њен допринос осветљавању поетике Иве Андрића. Посебан акценат биће стављен на њено виђење једног од најистакнутијих симбола у његовом дјелу: мост, који ће се сагледати из угла „трећег простора“ Хомија Бабе.

Кључне ријечи: Силија Хоксворт, Иво Андрић, мост, Исток, Запад.

Представљање доприноса Силије Хоксворт грађењу моста између наше и англосаксонске културе, њено служење „човеку и човечности“ и анализу њене студије Иво Анgрић између Исӣока и Зайаgа почећемо простом констатацијом коју је изрекао Зденко Лешић (и не само он) приликом обељежавања 50 година од додјеле Нобелове награде Иву Андрићу: Андрић је велики писац! Ова оцјена никад није доведена у питање: његово дјело остало је постојано као и његови мостови, док се ми читаоци, тумачи његовог дјела, мијењамо заједно са новим критичким приступима. Дух времена 
константно се поигравао и још увијек поиграва, док његово дјело и даље „служи човеку и човечности“. Оно служи и грађењу мостова између култура, које већ дуго подиже и Силија Хоксворт кроз преводе његових дјела (Проклейа авлија и gруіе ирриче, Ур; Травничка хрони$\kappa a$, Разіоовори са Гојом), и коначно писањем прве књиге о Андрићу на енглеском језику: Иво Анgрић између Истиока и Зайаgа.

Фасцинираност Силије Хоксворт дјелом Ива Андрића никада није престала, што изражава не само преводима Андрићевих дјела на енглески језик, већ и интервјуима које повремено даје. Тако из једног од 24. априла 2015. године сазнајемо да тренутно ради на преводу дјела Омер йаша Лайас за Њујорк Бук Ривју (New York Book Review). Почела је да се бави грађењем мостова између англосаксонске и наше културе поодавно: након студија руског и француског на Кембриџу, потом током једногодишњег боравка у Београду, завршетка магистарских студија из српскохрватског језика и књижевности на Факултету за славистичке и источноевропске студије, данас Одсјеку на Лондонском универзитету (University College London ), гдје је почела да предаје као лектор 1971. године. Десет година након што је Андрић освојио Нобелову награду Силија Хоксворт је покушала да уђе у тајне српскохрватског језика и Андрићеве поетике на примјеру романа На Дрини ћуӣpuja. Опчињавао ју је, како онда тако и данас, његов изузетно мудар и уравнотежен глас, како каже у поменутом интервјуу, заједно са „иронијом којом је обојио слику свог свијета“ (Иниеервју,1). У поменутом интервјуу она истиче и тијесну везу између биографског, културно-историјског и текстуалног: Андрићеву свијест о подјели народа на свим нивоима, његова искуства у Првом свјетском рату, Андрићево виђење 
Југославије као уједињавајућег принципа, начина да се помире завађени народи и коначно моста, како каже, подједнако уједињавајућег принципа „на свим нивоима“ (Иниетервју, 1). Андрић пише умно о природи и вриједности мостова (На Дрини ћуйрија), закључује Силија Хоксворт: он изражава оштар бол (трауму рата) оног тренутка када мост нестане и више не може да оствари циљ повезивања.

Опчињеност Силије Хоксворт дјелом Иве Андрића нашла је свој најбољи израз у критичкој студији Иво Андрић: мости између Истиока и Зайаgа, (првој и јединој на енглеском језику) у издању Атлоун Преса (The Athlone Press) из Лондона и Довера, коју је помогла Фондације Иво Андрић. Студија уводи англосаксонске читаоце лијепим и разговјетним језиком у све жанрове којима се Андрић бавио и то овим редом: поезију, приповјетке, романе, есеје и рефлексивну прозу. Након Предговора у коме ауторка напомиње да се први превод његовог романа Травничка хроника (Bosnian Story) на енглеском језику појавио 1958. године из пера Кенета Џонстона (Kenneth Johnstone), она наглашава да је интересовање за Андрићева дјела и њихово изучавање порасло у Британији и Америци тек након 1961. године, када је Андрић добио Нобелову награду. Ипак, овај узлет кратко је трајао, наставља Силија Хоксворт, jep је Андрић и даље запостављени писац у овом дијелу свијета и изучава се углавном у домену славистике. Зато је ауторка поставила себи за циљ да исправи ову неправду према великом писцу покушајем да преко своје студије приближи Андрића обичном англофоном читаоцу (ако такав уопште постоји!?) и са циљем да побуди обнову интересовања за његову поетику. Свим оним читаоцима који владају енглеским језиком свакако је омогућила риједак сусрет са Андрићем, јер је у 
овој изузетној студији дозволила да се чује његов глас кад год је то било могуће („speak for himself“), док ипак нисмо сасвим сигурни у којој је мјери у англосаксонским академским круговима, и да ли уопште, успјела да помјери границе у критичкој рецепцији његовог дјела.

Ипак, међу малобројним новијим одјецима критике о Андрићевој критици морамо издвојити глас истакнутог слависте Богдана Ракића (Ракић 2000: 88) који у својој оцјени Андрићеве критике издваја онај слој тумачења Силије Хоксворт који се односи на премошћавање етничких подјела у Босни, а који она препознаје у тематским патернама и сликама које често избијају на површину његових дјела. Он наводи мјесто у коме Силија Хоксворт приказује Андрића као аутора који је представљао најбоље стране сусрета муслиманског Истока и хришћанског Запада, управо онај тако познати Хоми Бабин „трећи простор“ (Баба 2006: 226) на коме обје културе добијају, а који је Андрићу омогућио да трајно дефинише најзначајнији симбол у његовом дјелу: мост (Ракић 2000: 88). Ракићу се придружује и Марина Антић која подробно анализира тумачења западних аутора Андрићевог романа На Дрини ћуйрија у културолошком контексту Босне да би закључила да нема услова да се овај роман чита као онај који је идеолошки мотивисан и да се не може свести само на једно завршено тумачење или пак увести у политички дискурс (Антић 2003: 9-17).

Силија Хоксворт води читаоце на енглеском језику ка Андрићевој поетици најприје их упознавајући са извором и духом његових дјела, Босном у освиту Првог свјетског рата, тачком сусрета Истока и Запада (хабзбуршке и отоманске империје). Андрић, како ауторка истиче, представља њен 
најсвјетлији израз, јер уводи „један од најважнијих симбола у свом дјелу: мост" (Ivo Andrić: Bridge Between East and West, 1). Мјесто сусрета Истока и Запада (Босна) има своје историјско и културолошко утемељење које Силија Хоксворт (1984) живописно описује као хришћанску земљу у којој „преовлађују минарети на урбаном небу, у којој су се аспекти исламских обреда увукли у хришћанске погледе, у којој је ваздух испуњен мирисом свјеже пржене кафе и опуштајућих наргила, са редовним оглашавањем мујезина и традиционалним словенским пјесмама. Оријентални и католички фестивали смјењују се и са светим празницима Ислама, док се богато украшена оријентална одјећа и храна продаје на пијацама заједно са хрватском и српском народном ношњом“ (4).

У таквој атмосфери рођен је Иво Андрић, каже даље Силија Хоксворт, атмосфери „обојеној помоћу три најистакнутија аспекта босанског живота: њених планина које мирно гледају с висине како пролазе генерације; њених разноликих култура; њених уских долина у којима мост постаје не само средство помоћу којег се прелази с једне на другу страну изоловане заједнице, већ и симбол повезивања људи без обзира на њихове културолошке разлике“ (5). Мост као симбол хуманости у срцу је Андрићеве поетике, закључује Силија Хоксворт, то је простор који ће константно опчињавати великог писца, јер ће се на њему и око њега преплитати историје и културе, легенде и митови, да би се временом трансформисали у пишчев умјетнички доживљај који и даље опчињава генерације и генерације читалаца.

Сусрет култура на Андрићевом мосту или на већ поменутом Хоми Бабином трећем простору, не одвија се само на видљивом плану. Он је далеко дубљи и сложе- 
нији, јер садржи нешто од онога што се да тешко дефинисати: silence (тишину/ћутање), што залази не само у тајне сјећања, већ и у дубље филозофске увиде. Силија Хоксворт уводи читаоце у Андрићеву синтагму „у ћутању је сигурност“ кроз причу „Мост на Жепи“ показујући им како „камени мост представља тихи спој између човјековог несхватања живота и његовог схватања хармоније која даје смисао његовом животу“ (9). Она наводи сам крај ове приче у коме се мост представља одвојеним и усамљеним без могућности да се споји или буде спојен са природом, већ остаје ухваћен у њеној замци. Ту замку ауторка идентификује у дјелима писца ухваћеног у расцјепу између западне културе која га је образовала

и „дивљих кречњачких планина Босне“ које су га, како каже, макар и дјелимично формирале.

Након увођења англофоних читалаца у биографију Иве Андрића, која садржи и његову лектиру у којој се издвајају Витман, Стриндберг, Гете, Кјеркегор, Сервантес, Иго и Томас Ман, Силија Хоксворт даје књижевни и историјски контекст настанка и објављивања његових дјела. Осим утицаја истакнутих писаца, посебну улогу у дефинисању његове поетике она приписује нашој усменој традицији, Вуку и Његошу и једном инспиративном детаљу: излогу књижаре. Ауторка тако ставља акценат на пишчев унутрашњи свијет истичући да је за Андрића „оно 'реално' био његов ум, његово креативно дјело“. (49) Његова потрага тицала се, како каже, „патерни и вјечитих истина, смјештених испод површине форми људске егзистенције, метафизичке димензије искуства“ (49). Она је исто тако лирска, јер „удружена са широким перспективама у његовим дјелима чини оно што осликава Андрићеве портрете кроз историју, док евоцирање митова и легенди помоћу којих уређујемо своје искуство, креира 
ону непосредност по којој се препознаје његово дјело“ (50). Ову непосредност као неки вид обрасца Силија Хоксворт идентификује у Андрићевој лирско-рефлексивној прози издвајајући неколико кључних симбола (мостови, лица, сунце) и његове ријечи да је увијек радио не једном те истом дјелу које би по објављивању добијало различита жанровска одређења (прича, пјесма, есеј) (50). Ове Андрићеве ријечи потврдиле су њено увјерење да је граница између жанрова код Андрића крхка, јер је прије свега имао на уму жељу да каже што више о „човеку и човечности“ приступајући му из различитих углова и перспектива. Илустрације ради, она преузима слику на којој почива Проклетиа авлија, да би закључила да „његово дјело конструише мање или више сложене кругове око нуклеуса који је представљен појединцем који се суочава са сопственим идентитетом у вртлогу људске судбине“ (50).

Крхка или не, жанрововска подјела Андрићевих дјела и критика многих наших и страних изучаваоца његовог дјела оставили су најдубљи траг на Силију Хоксворт и њено дефинисање Андрићеве поетике. То су, између осталих, Милош Бандић, Петар Џаџић, Мирослав Караулац, Станко Кораћ, Славко Леовац, Предраг Палавестра, Никола Милошевић, Живојин Станојчић, Иво Тартаља, Радован Вучковић, Војислав Ђурић, Бранко Милановић, Антоније Исаковић, Радован Поповић. Од страних аутора значајан утицај имали су: Клаудио Марабини, Регина Минде, Његош М. Петровић, Алберт Лорд, Никола Прибић, Вида Тарановски-Џонсон, Анте Кадић, Томас Екман, Васа Д. Михаиловић и Едвард Денис Гој. Њихова проучавања Андрићевог дјела омогућила су Силији Хоксворт да у поетици Иве Андрића препозна четири сродне области које је, како каже, Андрић наслиједио из своје културе: 
a) фасцинација јазом између материјалне егзистенције и имагинације, б) Андрићево занимање за тачке сусрета између историјских догађаја и начина на који их примамо и тумачимо, в) стилизација свијета умјетности која је јасно одвојена од материјалног свијета, и г) устрепталост у сусрету са умјетничким дјелом (237-241).

Силија Хоксворт објашњава прву област (фасцинација јазом између материјалне егзистенције и имагинације) улогом усмене традиције, поготово херојских пјесама, које се не баве, како каже, „свакодневним животом, већ човјековом потребом за редом и значењем“ (237). Ово тврђење илуструје примјером из дјела $H a$ Дрини ћуйрија у коме приказује јунака Алију Ђерзелеза, кога не обожавају само муслимански дјечаци, већ представља извор чуђења и инспирације за одрасле који, како каже „вјерују у његов повратак на земљу кадгод буде потребно“ (237). Само вјеровање које изражава дубоко укоријењену потребу за херојима и вођама може постати дословно реалност у којој се, како каже, овај јаз сужава и коначно укида тако да се брише разлика између онога што су представљали у одређеним историјским околностима и начина на који су опстајали у имагинацији људи.

Друга област сродна је првој и односи се на тачку сусрета историјских догађаја и начина на који се прихватају и тумаче. Као примјер, Силија Хоксворт узима различите реакције француских и аустријских конзула и турских везира у Травнику у Травничкој хроници у односу на једне те исте догађаје да би закључила да је „сам Андрић живио у добу свеопште митологизације скорашње историје, због чега његово дјело обилује примјерима 'процесирања' историје на јавном и личном плану (238).

Трећа област односи се на стилизацију свијета умјетности који је код Андрића јасно одвојен од материјалног свијета. Силија Хоксворт узима као примјер 
причу „Панорама“ да би илустровала комплексност овог одвојеног односа у коме фотографија треба да прикаже реалност, али и да истовремено побуди свијет имагинације. Овај свијет „радикално се не разликује од оног у коме живимо, није ни супериорнији ни инфериорнији, већ је одвојен, разликује га само чињеница да постоји у нашем уму. Он је, другим ријечима, слика која сугерише свијест о сопственој извјештачености, која јој у ствари додаје вео мистерије, позивајући читаоца да размишља не само о садржају приче, већ и о разлозима због којих неко жели да је исприча“ (239).

У тијесној вези са трећом области је четврта, која се односи на усхићење читаоца. Силија Хоксворт га илуструје Андрићевим сјећањима и сликама из Прокле$\bar{u} е$ авлије када се брат Петар буди и види књигу поред себе, да би се вратила на улогу епске поезије у дефинисању његове поетике и закључила да: „ритуализована форма њиховог извођења, попут физичког присуства књиге, ствара осјећај ишчекивања да пјесма може садржати важну поруку у оквиру својих јасно оцртаних граница и стилизоване форме“ (240).

Одлике овако дефинисане поетике Андрић је наслиједио од своје културе и оне се рефлектују у описаном сусрету између материјалног и имагинативног свијета. Неке идеје препознају се кроз колективну манифестацију мита и легенде, а неке у виду појединачних опсесија и илузија. Констатујући да Андрић није инсистирао на јасној разлици између мита и легенде, Силија Хоксворт закључује да јесте правио разлику између „позитивних“ (Алија) и „негативних“ (Омер-паша Латас) легенди које је касније фикционализовао у својим дјелима. Такође, присутан је велики број ликова који живе под теретом опсесија, а које могу бити последица стицаја околности (Мара милосница, Мустафа Мађар, Аника), или границе 
на ивици између „душевно здравих“ и „душевно болесних“ (Карађоз) ликова. Прати их и терет илузија („Јелена, жена које нема"), који их чини реалнијим од саме реалности, што им даје посебан квалитет. У тијесној вези са разумијевањем ових одлика Андрићеве поетике јесте и перспектива која директно утиче на разумијевање њихових комплексних значења. Нешто ћемо разумјети као есенцијелно илузорно или фундаментално истинито зависно од перспективе посматрача, каже Силија Хоксворт, што опет значи да је обоје исправно: „свака перспектива 'истине' је илузорна, и истовремено је 'истинита' ако у себи носи значење“ (244).

Силија Хоксворт заокружује увођење читалаца у Андрићеву поетику освртом на Андрићев однос према самом процесу писања (Проклетиа авлија) и издвајањем слике затвора као метафоре живота из које Андрићеви ликови покушавају да изађу. Решење је слика моста у сваком смислу и зато она издваја ону коју даје Андрић у есеју „Мостови“, што јој омогућује да јасно заокружи тему коју је дуго истраживала. Све се не налази „с друге стране“ у „ономе што није ово“, у осјећају незавршености, непотпуности који „константно тражи разрешење“ (247). И потом каже:

Ипак, осим централне слике моста, у Андрићевим дјелима може се препознати замисао да све разне манифестације живота отелотворују и изражавају нешто обухватније од њих самих. Андрићева дјела прецизно су документована, детаљна и конкретна. $\mathrm{OH}$ избјегава анализу и апстрактно по сваку цијену. Он у потпуности користи Босну и детаље из њене историје да би изнио цијело богатство идеја које црпе своју снагу и сложеност из контекста. Тако, он пише нашироко о отоманском царству. То му омогућава да предочи идеје о таштини земаљске власти, арбитрарној власти 
и опресији, а да при том не каже ништа директно. Судар култура у бити његовог дјела једнако доноси плодоносне идеје без спољашњег коментара. Психолошка и емоционална стања Андрићевих ликова описана су у погледу њиховог доживљаја материјалног свијета. Страхови нису апстрактни, они потичу из ситуација у којима се затекну и постану интегрални дио перцепције посматрања других. Слично томе, у свим Андрићевим приказима разних конфронтација, моћ и рањивост респективних ликова представљају се у погледу њихових психолошких атрибута, кретања и покрета. (248)

Коначан закључак Силије Хоксворт долази из анализе Проклешете авлије, или, како је још назива, „креативног причања приче у затвору“ (248) коју закључује ријечима са којима ћемо се сложити у овом штуром представљању ове изузетно значајне студије: „У бескрајно бијелој и безобличној празнини која представља проток времена у спољашњем раму, све што опстаје јесте причање приче која се одвија у души човјековој“ (249). Епилог Проклетее авлије подсјећа да не постоји ништа друго и да је опстанак једнако важан колико је и рањив.

\section{Извори и литература}

Antić, Marina. „Living in the Shadow of the Bridge: Ivo Andrić’s the Bridge on the Drina and Western Imaginings of Bosnia", Spaceafidentity 3/3, 2003, 9-17.

Bandić, Miloš. Ivo Andrić: zagonetka vedrine. Novi Sad: Matica srpska, 1963.

Баба, Хоми. „Колонијална и постколонијална теорија: разго-

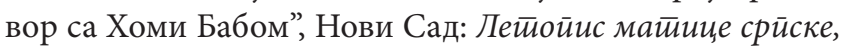
јануар-фебруар, 2005.

Bosnian Story, translated by Kenneth Johnstone. London: Lincolns Prager, $2^{\text {nd }}$ edn. 1961. 
The Bridge on the Drina, translated by Lovett Edwards. London: George Allen and Unwin, 2 ${ }^{\text {nd }}$ edn. 1961.

Eekman, Thomas. "The later stories of Ivo Andrić". The Slavonic and East European Review.

Coote, M.P. "Narrative and narrative structure in Ivo Andric's 'Devil's Yard"'. Slavic and East European Journal, Madison, 21, 1977.

Delo Ive Andrića u kontekstu evropske knjizevnosti $i$ kulture. Beograd: Zadužbina Ive Andrića, 1981.

Džadžić, Petar. Ivo Andrić. Beograd: Nolit, 1957.

Đurić,Vojislav. Ur. Ivo Andrić, Beograd: Institut za teoriju knjizevnosti i umetnosti, 1962.

Goy, E.D. "The work of Ivo Andrić", London: The Slavonic and East European Review, 1963.

Hawkesworth, Celia. Ivo Andrić: Bridge Between East and West, London and Dover: Athlone Press, 1984.

Interview with Celia Hawkesworth - translator of Balkan Literature, posted by Richard Dion on April 24, 2015 in Conceptual.

Isaković, Antonije. Zbornik radova o Ivi Andriću. Beograd: SANU, 1976.

Karaulac, Miroslav. Rani Andrić. Beograd: Prosveta, Sarajevo: Svjetlost, 1980.

Kadić, Ante. "The French in 'The Chronicle of Travnik", University of California Press: California Slavic Studies.

Kazivanja o Andriću. ed. Radovan Popović. Beograd: Sloboda, 1976.

Korać, Stanko. Andrićevi romani $i$ svijet bez boga. Zagreb: Prosvjeta, 1970.

Leovac, Slavko. Pripovedač Ivo Andrić. Novi Sad: Matica srpska, 1979.

Marabini, Claudio. "La Narrativa di Ivo Andrić”. Nuova antologia di lettere, arti e scienze, vol. 499, 1967.

Mihailovich, Vasa. "The Basic World View in the Short Stories of Ivo Andrić”. The Slavic and East European Journal, 1966.

Milošević, Nikola. Andrić i Krleža kao antipodi. Beograd: Slovo ljubve, 1975.

Milanović, Branko. Ivo Andrić u svjetlu kritike. Sarajevo: Svjetlost, 1977.

Minde, Regina. Ivo Andrić. Studien uber seine Erzdhlkunst. Munich: Verlag Otto Sagner, 1962.

Palavestra, Predrag. Skriveni pesnik. Beograd: Slovo ljubve, 1981.

Pribić, Nikola. "Ivo Andric and his Historical Novel The Bridge on the Drina"' The Florida State University Papers, 1969. 
Rakić, Bogdan (2000). “The Proof is in the Pudding: Ivo Andrić and His Bosniak Critics" (PDF). Journal of the North American Society for Serbian Studies. Bloomington, Indiana: Slavica Publishers. 14 (1): 81-91. ISSN 0742-3330.

Stanojčić, Živojin. Jezik $i$ stil Iva Andrića. Beograd: Filološki fakultet, 1967.

Taranovski-Johnson, V. "Ivo Andrić’s 'Kuća na osami': Memories and Ghosts of the writer's past", Fiction and Drama in Eastern Europe, Columbus, Ohio; Slavica, 1980.

Tartalja, Ivo. Pripovedačeva estetika, Beograd: Nolit,1979.

Vučković, Radovan. Velika sinteza o Ivi Andriću, Sarajevo: Svjetlost, 1974.

\title{
Radojka Vukčević
}

\section{CELIA HAWKESWORTH'S BRIDGE BETWEEN EAST AND WEST}

\begin{abstract}
Summary
The paper discusses the contribution of Celia Hawkesworth to Ivo Andrićs poetics through analysis of her critical study Ivo Andrić: Bridge Between East and West. Special attention is paid to the central symbol in Andrićs pivotal novel The Bridge on the Drina: the bridge in Andrićs cultural background. Celia Hawkesworth's identification of Andrićs four related areas inherited from his cultural background is pointed out: a) a fascination with the discrepancy between material existence and the life of the mind b) the points of contact between historical events and the way they are received and interpreted 3) the stylization of the world of art d) the sense of excitement a work of art may arouse. The conclusions emphasize Celia Hawkesworth's recognition of Ivo Andrićs story telling in the mind of a man - the story of how to be human.
\end{abstract}

